\title{
Study of Business English Classroom Teaching Practice Driven by Output-oriented Approach
}

\author{
Guo Qin \\ School of Foreign Languages, Tianhe College of Guangdong Polytechnic Normal University, \\ Guangzhou510000, China. \\ 369002137@qq.com
}

Keywords: output-oriented approach; driving; Business English; classroom teaching practice

Abstract: Under the condition of information environment, teachers should combine the output-oriented method with the integrated teaching mode, and the output-oriented method can improve students' English autonomous learning ability and innovative ability. Considering the language deficiency of middle and advanced English students, the targeted College English teaching shall be carried out. With correct guidance and help, teachers can communicate closely with students. This will help to form the interaction between teachers and students, get rid of the traditional classroom teaching mode, and then stimulate their initiative in independent learning. Taking the expressive and practical topics and contents that students care about, teachers should make full use of various factors and teaching resources in output-oriented teaching, integrate sight, listening and speaking into one. According to the teaching concept and classroom design of the output-oriented method, a planned and step-by-step English classroom teaching practice is carried out to further enhance practical English competence.

\section{Introduction}

As an important basic course in Chinese higher education, the purpose of business English teaching is to cultivate students' English language ability. At present, our students' English learning is still mainly classroom learning. Therefore, how to do a good job in classroom teaching has become an important topic in business English teaching ${ }^{[1]}$. At present, the traditional teaching method is still widely used in business English teaching in our country. Teachers emphasize the language input to the students in the classroom, but ignore the opportunity to provide the students with the language output, which results in the imbalance between the input and the output of the students. Therefore, it hinders the development and improvement of students' language use ability. In addition, in the process of English teaching, vocational college English education has not fully implemented and embodied the concept of cultivating students' English application ability, and the students' practical English application ability has not been significantly improved ${ }^{[2]}$. Therefore, we need to find an effective way to improve the current situation of business English teaching, improve 
students' listening, speaking, reading, writing, translation and so on, so as to meet the requirements of social development and economic development for college students' English proficiency ${ }^{[3]}$.

The "output oriented method" (POA) is a teaching theory with Chinese characteristics proposed by Professor Wen Qiufang of China Foreign language Education Research Center of Beijing Foreign Studies University and led by POA team ${ }^{[4]}$. The theory system of "output-oriented method" consists of three parts: teaching idea, teaching hypothesis and teaching process. The teaching ideas include the theory of learning center, the theory of integration of learning and application, and the theory of whole person education. Teaching assumptions include output-driven, input-driven and selective learning. Teaching idea is the guiding ideology of teaching hypothesis and teaching process, teaching hypothesis is the theoretical support of teaching process, and teaching process is the realization form of teaching idea and teaching hypothesis. In the process of business English classroom teaching, the teaching mode driven by output-oriented method has become the norm. Through the practice of business English audio-visual speaking classroom teaching, this paper analyzes the practical and efficient business English production-oriented driving strategy, which can make up for the deficiency in teaching practice and make it achieve the expected teaching effect. To carry out the production-oriented English teaching, select the topics and contents of students' concern, interest, expressiveness and practicability, and make effective use of the various factors and teaching resources in the production-oriented teaching, and integrate vision, listening and speaking into one. Combined with cultural comparison of audio-visual teaching, attention should be paid to the choice of classroom contents and topics, and teachers, as the dominant teachers in the classroom, should pay attention to the topics and contents that students are concerned about. This paper briefly analyzes how to apply the output-oriented method in business English classroom teaching, and puts forward specific teaching strategies to promote the effective extension of business English classroom teaching and improve the classroom teaching efficiency.

\section{Necessity of constructing business English classroom teaching system}

\subsection{Deficiency of traditional teaching}

Language itself has strong practicality and application. As a language subject, business English should emphasize its practicality and application, and practical teaching should play an important role in business English teaching. However, for a long time, due to various reasons, such as the traditional examination-oriented concept, the large group of learners, the lack of practice place, the high cost of practice, the compression of study hours and so on, the curriculum of business English in our country is basically a theoretical course. Teaching is mainly in the form of classroom instruction, teachers can only arrange some practical content in class or through homework after class $^{[5]}$.

\subsection{Requirements of Business English reform}

The Business English Teaching Guide still regards "training students' English application ability" as the primary teaching goal of business English. This not only shows the importance of business English classroom teaching, but also shows that we have a big gap in this link. Therefore, it is the requirement of the reform and development of higher education to plan the content of the practice nature in the business English classroom teaching to the practical teaching link, and to construct the business English classroom teaching system, which will become the inevitable trend of the business English teaching reform ${ }^{[6]}$. 


\section{Construction of Business English classroom Teaching system based on POA}

The optimum design of business English classroom teaching driven by output-oriented method can effectively teach according to the learning situation of middle and senior students, strengthen the cultivation of English knowledge at the primary stage, and activate English knowledge effectively by using output-oriented method, so as to use it flexibly. In practice teaching, through consolidation and loss Output-oriented method is feasible to some extent. It requires students to have perfect psychological cognition and analysis, inductive ability, ability to learn experience and verify knowledge. These abilities are all possessed by junior students, but there are great differences in language output. Therefore, output should be guaranteed ${ }^{[7]}$. It is simple and easy to do. It is helpful to stimulate students'desire for English language expression and increase their chances of language practice to strengthen students' enthusiasm for English learning through output evaluation.

\subsection{Feasibility of constructing Business English classroom teaching by output-oriented method}

The practicality and application of language are mainly reflected in output skills (say, write, translate). This is exactly what the POA emphasizes, from teaching English to teaching students to use English, that is, practice. Therefore, fundamentally speaking, the POA and the strengthening of business English classroom teaching objectives are consistent. Professor Wen Qiufang's detailed discussion on the POA will provide an important theoretical basis and practical guidance for the construction of business English classroom teaching system ${ }^{[8]}$.

\subsection{Specific requirements}

To construct the practical teaching system of business English, we must plan systematically from many aspects, such as teaching goal, course setting, teaching content, teaching organization, assessment and so on. The formulation of teaching objectives includes the planning of the overall teaching objectives and the specific objectives of each practical task. These goals must be in line with the overall higher education talent training goals and business English curriculum system objectives. At the same time, the requirement of "output" must be clearly embodied, that is to say, students should use the three skills of speaking, writing and translation to accomplish activities of potential communicative value. Increasing the practical teaching links will inevitably require the adjustment of the original business English curriculum system ${ }^{[9]}$. First of all, it is necessary to re-plan the original classroom teaching contents and transfer the practical activities of the original classroom teaching contents to the practical teaching. The practical teaching can be subdivided into interpretation practice and translation practice according to the output skills. Writing practice and oral practice and other specific courses. According to their own characteristics and future career goals, students take one or two courses. At the same time, the reasonable arrangement of theory teaching and practice course, including the proportion of hours, the time period collocation and so on. It is necessary to give full consideration into the characteristics of each specific task of practical teaching, and to arrange the time reasonably, such as the practice teaching which is closely related to the content of the theoretical teaching materials should be arranged synchronously with the theoretical teaching. The practice teaching separated from the theory teaching materials can be arranged separately at the beginning or end of the term.

The design of business English classroom teaching content must aim at "output", and the output task must have potential communicative value. Output tasks can cover daily communication, cross-cultural communication, English talent show, English workplace skills, English academic skills, second class activities, etc. Specific to each practical course, need to formulate specific teaching tasks, form their own syllabus. The POA emphasizes that input is the enabling means to 
accomplish the output target task, and the teacher should provide appropriate, multi-modal language materials and knowledge content for the students. Students should actively search for relevant language and knowledge materials through multiple channels in order to achieve the set output target.

Because the group of business English learners is large, the practice place is limited, the practice cost is high, it is not realistic to arrange the field practice in the real context, so the business English classroom teaching organization can adopt the combination of class and extracurricular. A combination of school and outside. As far as the present situation is concerned, it is still the main teaching place in class and in school. According to the intrinsic requirements of the POA, the teacher should carefully study the key points and difficulties in each output target, carefully analyze the language forms and knowledge content in the input material which can serve the output, and then design the teaching steps on this basis. Make clear to the students in class the task goal, the concrete steps and requirements to realize the goal, the form and standard of task acceptance check, etc. At the same time, teachers should make clear to students which links are carried out in class, which links should be completed after class and even outside school. In addition, teachers should monitor the process of students' achievement of task goals. The organization of business English classroom teaching aiming at specific output task is similar to the experimental course of science and engineering. Some colleges and universities introduce the important elements of science and engineering experiment into language teaching and practice, and construct the experimental teaching system of business English ${ }^{[10]}$.

According to the application requirements of the output-oriented method, the assessment criteria should be specific and the methods should be varied. Accurate understanding of the assessment criteria is the premise of students' practice and application of the standard to complete the output task. Therefore, when devolving the target task, we must study the assessment criteria of collective learning, and it is better to combine with specific cases. There should be a variety of assessment methods, especially in oral or interpreting practice classes. If not all students can do class presentations, then there are other methods of assessment for students who do not report, such as putting videos on public platforms. Teachers and students judge together.

\section{Practice of Business English classroom Teaching based on POA}

\subsection{Driving stage to improve students' desire for language expression}

The driving stage is that teachers can communicate online, which can stimulate students' desire for language expression and improve students' English language expression ability. Teachers can use English topics, such as video playback, in English teaching drivers. The video, for example, shows "the Internet can change people's daily lives," but it is not explained in the video, but only in pictures and words. Teachers set up teaching tasks: after watching the video, describe what you think is the most shocking aspect of the video, and introduce how the Internet can change your life according to the actual situation of your life. When the students finish the task, they will find that there are some problems in the description, such as insufficient language. The teacher can set a good example for the students by interpreting the video simultaneously, and create a good environment for language communication. In order to stimulate students' desire for English language learning.

\subsection{Promoting stage to improve students' initiative in English learning}

The facilitation stage is also called the English text input stage. Teachers encourage students to complete the output of knowledge according to group cooperation or dialogue and discussion, so 
that students can feel the deficiency of knowledge in the process of practice. Therefore, it is helpful to perfect the knowledge system of English. Teachers set specific teaching tasks for students. For example, in English unit learning, students can be asked to debate English according to the advantages and disadvantages of Internet use, which can enhance students' understanding and cognition of online honesty and lies. It can improve the students' language expression ability and English thinking ability, and it can also lay a solid foundation for the students' future study and improve their English comprehensive accomplishment. In English text teaching, teachers can encourage students to master the content structure of English articles in the form of role-playing, and organize the stories into a complete dialogue so that students can display them randomly in the classroom. Can enliven the classroom atmosphere, make the student feel that he is the master of the classroom, can go deep into the article, understand the context in it and express it. It can not only get rid of the traditional teaching mode of rote memorization, but also follow the teaching principle of learning and using as a whole. Improve students' initiative in English learning.

\subsection{Evaluation stage to stimulate students' Self-confidence in English learning}

When students complete their language teaching goals and learning tasks, teachers should carry out an objective and comprehensive evaluation of the students, which can be carried out by means of mutual evaluation between teachers and students, between students and students, and between groups, and so on. Help students to better discover the problems and shortcomings in the process of English learning, and experience the gains and fun of English learning. After the students show their English activities, teachers should analyze the students' advantages and disadvantages, affirm the students' advantages, and correct the students' language usage and grammatical errors in English activities in a timely manner. We pay attention to the stage evaluation of students, so as to stimulate students' confidence in English learning, and better carry out autonomous learning and inquiry.

\section{Conclusions}

This paper studies the optimization of business English classroom teaching practice. Teachers should innovate the teaching mode, actively combine the output-oriented method, innovate the teaching idea, strengthen the effective combination of the input learning and the productive task, and improve the students' English proficiency. The output-oriented method regards output as the goal of learning, promotes the output with the input, and drives the input with the output. This kind of teaching method really practices the "learning-centered" teaching concept. All the teaching activities are carried out around the productive tasks and learning activities of communicative value, which enable students to construct knowledge actively, selectively screen out useful information related to the subject, and achieve the purpose of learning while using, learning and using, and improving the learning efficiency. Of course, in the teaching process, also need to give full play to the leading role of teachers. Although the theory of POA is still in the period of development and perfection, it is very worthwhile to try and practice this model for the purpose of teaching reform at present. In business application classroom teaching, teachers should set up life-long learning idea, innovate good classroom atmosphere, be able to take the production-oriented method as teaching guideline, and promote students' self-cognition by constructing pre-class driving and class tasks. Carry out objective and comprehensive evaluation to cultivate students' interest in English learning. In business English teaching class, we should make use of various factors and teaching resources in production-oriented teaching, integrate vision, listening and speaking, and plan according to the teaching idea and classroom design of production-oriented method. Step by step English classroom teaching practice, further improve students' English practical ability, improve classroom teaching level. 


\section{References}

[1] Hu Jichang. A study on the needs of WeChat in College English listening and speaking Teaching [J]. Curriculum education research,2016, 23:127.

[2] Wen Qiufang. Output driven hypothesis and English professional skills curriculum reform [J]. foreign language community, 2008(02): 2-9.

[3] Wen Qiufang. Application of output-driven hypothesis in college English teaching: reflections and suggestions [J]. Foreign language community,2013(06): 14-22.

[4] Wen Qiufang. To construct the theory system of "output oriented method" [J]. Foreign language Teaching and Research, 2015, 47(04): 547-558,640.

[5] Li Yue. Application of output-driven, input-driven hypothesis in tourism English teaching: a case study of Chuzhou University [J]. Journal of Chifeng University (Natural Science Edition), 2014, 30(19): 219-221.

[6] Luo Yuanyuan, Zeng Yuanyuan. This paper analyzes a public English course in higher vocational education from the practical point of view-taking the fifth "Foreign Teachers' Cup" as an example of one of the entries in Guangxi Competition [J]. Guangxi education, 2014(47): 36-37+58.

[7] Wang Li-song. A New approach to College English Teaching Reform from the Perspective of Exput-Driven-Input-Driven hypothesis [J]. Chinese Journal of Education, 2015(S2): 84-85.

[8] Tian Yanyan. The Application of Exput-Driven-Input-Production hypothesis in College English Teaching-A case study of Public English Class for Marketing students [J]. Contemporary educational theory and practice, 2015, 7(08): 123-126.

[9] Wang Shouren, Wang Tsunami. The present situation of College English Teaching in China and the Reform and Development Direction of College English Teaching [J]. Chinese foreign language, 2011, 8(05): 4-11, 17. 